\title{
O POLÍTICO E O BURLESCO NA MANGUEIRA 2018: ARQUITETURA E SENTIDOS
}

\author{
TIAGO JOSÉ FREITAS BATISTA ${ }^{1}$
}

\author{
Universidade Federal do Rio de Janeiro/ Faculdade de Letras \\ Programa de Pós-graduação em Linguística - Av. Horácio Macedo, 2151, Sala F 309, \\ CEP 21941-917, Cidade Universitária, Rio de Janeiro, RJ - Brasil \\ tiagofreitas.professoregmail.com
}

\begin{abstract}
Resumo. Este artigo apresenta e classifica um entrelaçamento linguístico entre discursividade - através dos sentidos e arquiteturas - e a arte representada pelo samba-enredo e fantasias - do desfile da Estação Primeira de Mangueira para o Carnaval de 2018 que apresenta o enredo: "com dinheiro ou sem dinheiro, eu brinco". Nossas análises se balizarão no método pecheutiano da AD e na arquitetura do não-verbal, em Souza, objetivando identificar o político e o burlesco na materialidade mensurada, extraindo dela posições, condições de produção, ideologia, memória e demais elementos que inscrevem o desfile da agremiação carnavalesca em um ato de manifestação popular contra o maior mandatário da cidade do Rio de Janeiro: o prefeito Marcelo Crivella.
\end{abstract}

Palavras-chave: sentidos; arquiteturas; político; mangueira; burlesco.

\begin{abstract}
This article presents and classifies a linguistic interweaving between discursiveness - through the senses and architectures - and the art represented by the samba - plot and fantasies - of the parade of Estação Primeiro de Mangueira for the Carnival of 2018 that presents the plot: "with money or no money, I play. "Our analyzes will be based on the pecheutian method of $A D$ and non-verbal architecture in Souza, aiming to identify the political and the burlesque in the measured materiality, extracting from it positions, conditions of production, ideology, memory and other elements that inscribe the parade of the carnival association in an act of popular demonstration against the mayor of the city of Rio de Janeiro: Mayor Marcelo Crivella.
\end{abstract}

Keywords: senses; architectures; political; hose; burlesque.

\section{INTRODUÇÃO}

Este artigo tem por objetivo aprofundar os estudos de Carnaval em âmbito de discurso, promovendo para essa importante celebração brasileira, espaços outros que não se limitam às discussões culturais e sociais. $\mathrm{O}$ carnaval dessa investigação está filiado aos

\footnotetext{
1 Doutorando em Linguística pela Universidade Federal do Rio de Janeiro, com bolsa da CAPES; pesquisador no observatório de Carnaval do Laboratório de Estudos do Discurso, Imagem e Som LABEDIS/UFRJ do Museu Nacional.
} 
aparatos da análise de discurso em Michel Pêcheux (1969 e 1999), Eni Orlandi (2006 e 2007) e Tania Souza. (2001 e 2002).

Nossas análises, em um primeiro momento, apresentam o Carnaval como uma tríade de acontecimento rodeado de atos políticos, discursivos e históricos, que perpassa pela escolha do enredo a ser narrado na avenida e do processo de eleição do samba-enredo a ser cantado pela comunidade durante o ano. Em um segundo momento, abordaremos as condições de produção que culminaram na formação discursiva "com dinheiro ou sem dinheiro, eu brinco", tema de enredo da agremiação Estação Primeira de Mangueira nos desfiles de 2018. No último momento, apresentaremos as arquiteturas e sentidos produzidos no discurso, cuja materialidade será a letra do samba-enredo e três fantasias, que operam significando em atos políticos e burlescos na cidade do Rio de Janeiro.

\section{ESCOLAS DE SAMBA: DISCURSO E CARNAVAL}

A fundação do pensar o Carnaval enquanto materialidade discursiva ocorreu nos idos dos anos 2000, em um projeto desenvolvido por Tania Clemente de Souza. Na ocasião a pesquisadora agrupou em um artigo inúmeras análises relacionadas principalmente à memória alegórica que as agremiações carnavalescas do Rio de Janeiro utilizaram em seus enredos em celebração aos 500 anos do "descobrimento do Brasil". A pesquisadora partindo de conceitos trazidos pela escola francesa de Análise de Discurso (AD) pretendeu, pois,

verificar como se constituiu a narrativa da descoberta do Brasil pelas Escolas de Samba. Em síntese, interessou explicitar a relação entre paráfrase e polissemia materializada nas narrativas de escolas de samba, tomando como base o estatuto de imagens fundadoras de uma memória discursiva outra - aquela instituída pelo carnaval.

Ao transcorrer dos anos, a retomada do pensamento "discurso e carnaval" é trabalhada por Batista (2017) em sua dissertação de mestrado em letras, principalmente no que consiste ao analisar o imaginário das Escolas de Samba sobre a Amazônia brasileira e ao sujeito indígena. Seus registros também aparecem em artigos publicados em revistas científicas que relacionam as questões identitárias em escolha de enredos e, sobretudo nas relações de força entre posições sujeitos -patrocinado e patrocinador - e que se estende atualmente em sua tese de doutorado em linguística com olhares avançados sobre AD e o Carnaval.

Ao longo desse texto vamos constituindo inúmeros aparatos da análise de discurso na relação com o Carnaval como, por exemplo: a) a noção de acontecimento; b) memória; c) condições de produção; d) silêncio; e) posição sujeito; f) imaginário; g) relações de força e h) deslizamento.

As Escolas de Samba oferecem uma gama de múltiplos elementos a serem analisados em âmbito discursivo porque embora estejam autorizadas a narrar o que quiserem, quando narram, se filiam à posições discursivas através de sua materialidade que se alegoriza através de carros, fantasias, adereços e samba-enredo. A AD das nossas investigações respeita o estado catártico e misterioso que o carnaval provoca nas pessoas, mas extrai elementos da memória, do político, do acontecimento, do ideológico, das 
condições de produção, passando a ser o carnaval dos efeitos, das arquiteturas e dos sentidos.

Quando uma escola $\mathrm{X}$ da Comunidade $\mathrm{Y}$ resolve homenagear uma república ditatorial no Carnaval, ela se inscreve em uma posição ideológica e significa ao longo da avenida. Outro ponto que não nos foge é que quando uma narrativa é financiada por alguma empresa, ou estado, ou país, há na confecção desse desfile, inúmeras posições, a saber: I- do autor carnavalesco, II- do presidente da agremiação, III- dos membros desfilantes e IV- do sujeito patrocinador, por essa razão, há incidência de relações de força, que ocasionará um sentido na avenida com efeitos na imprensa, nos jurados e nos expectadores. Pelo exposto, é o Carnaval palco não só de espetáculo, mas também de uma materialidade que emite cenários e possibilita múltiplas análises, como passaremos a explanar a partir da próxima seção, cujo conteúdo analisado é o do desfile do ano de 2018 da Escola de Samba Estação Primeira de Mangueira.

\section{CARNAVAL DA MANGUEIRA 2018: O POLÍTICO, O DISCURSIVO E O HISTÓRICO}

A sucessão de acontecimentos narrados ao longo dos desfiles de Carnaval constituí um enredo. Enredo é o tema escolhido pelas Escolas de samba para a disputa carnavalesca com as demais agremiações, é através dele que toda a comunidade, desfilantes, mídia e jurados associam a escola $\mathrm{X}$ à uma sucessão de elementos narrativos, expressos através de alegorias, adereços, fantasias e samba-enredo.

$\mathrm{Na}$ constituição do formato, os enredos apresentados pelas agremiações são os mais diversificados possíveis: histórias reais, fictícias, recortes históricos, literários, folclóricos, biográficos e os patrocinados, esses, envolvendo principalmente homenagens à cidades, estados e países.

O processo de escolha do enredo a envolver o projeto anual de uma Escola de Samba é tomado principalmente pelo seu presidente. Há inúmeros fatores que podem subsidiar a escolha de um tema. Esse ato - político - é tomado para satisfazer o anseio de dois sujeitos: a) a comunidade (contingenciada por desfilantes) e b) o departamento de marketing, geralmente atento às linhas de patrocínio que oferecem altos subsídios financeiros em troca de serem narrados na avenida. Os desfiles da contemporaneidade exigem uma série de investimentos para deixarem as agremiações competitivas. Há uma série de elementos modernos que fazem parte do cotidiano carnavalesco das Escolas que projetam altas alegorias ornamentadas com iluminação temática, shows nas apresentações das comissões de frente, fantasias com acabamentos luxuosos e materiais minuciosos e outros aspectos que a tornam o evento uma parada de espetáculos. $O$ poder político de escolha, se estende para a eleição do samba-enredo a ser cantado pela comunidade, através de um concurso com eliminatórias nas quadras das agremiações, cabendo a decisão ao agente político máximo da Escola.

Esse acontecimento - político - da escolha do enredo e definição do samba-enredo que é tomado geralmente pelos dirigentes de uma Escola de Samba, antecede os dois outros acontecimentos: o histórico e o discursivo, que operam na tríade de um desfile carnavalesco. 
Uma agremiação ao escolher o enredo para ser contado na avenida "funda" a noção de acontecimento histórico, isso ocorre porque os desfiles de carnaval aparecem segundo Souza (2002, p.4) "não só como pano de fundo, mas enquanto acontecimento, como o grande operador discursivo, constituinte primeiro de toda a produção discursiva". Essa criação discursiva produzirá efeitos e sentidos em toda exibição na avenida através de uma materialidade, essa, consistirá no acontecimento discursivo visto que "se materializa nas alegorias e a história se carnavaliza" (SOUZA, 2002, p. 9).

No tocante ao acontecimento político, a Estação Primeira de Mangueira, optou pelo enredo: "com dinheiro ou sem dinheiro, eu brinco", adotando o tom da crítica diretamente ao prefeito do Rio de Janeiro, Marcelo Crivella, que efetivou cortes financeiros de 50\% nos subsídios às Escolas de Samba da edição de 2018 do Carnaval carioca. Paralelamente, a agremiação inscreve uma crítica moderada ao modelo da espetacularização em que o Carnaval está inserido, na contemporaneidade.

O acontecimento histórico "consiste em um fato que, por sua relevância enquanto ocorrência no mundo, passa a ser rememorado na história, fazendo parte do dizer sobre o passado de um povo, narrado pela ciência histórica" (LE GOFF, 1996 apud DELASILVA, 2008). Compreendemos como acontecimento histórico no Carnaval, as tratativas do que pretende ser narrado na avenida, ou seja, o enredo bruto concedido pelo o que se tem na história. Dessa forma, notamos que a Escola Mangueira, optou "historizar" o burlesco. Souza (2002) aponta que

na época de Rabelais, conta-nos Bakhtin (1996), o carnaval (e as demais festas populares) tinha, na base de seus sistemas de imagens, a constituição de "atos simbólicos dirigidos contra a autoridade suprema, contra o rei[...]. Nesse sistema, o rei é o bufão, escolhido pelo conjunto do povo, escarnecido por esse mesmo povo, injuriado, espancado, quando termina o seu reinado". O carnaval é entendido assim como uma forma burlesca de insurreição, de crítica, de protesto. E por que não de liberação? Nos dias atuais, podemos ver que este continua sendo um traço marcante do carnaval, na forma da irreverência e da fantasia. Lendo Burke (1989), percebe-se a confirmação desse traço, quando o carnaval é visto como "uma época de desordem institucionalizada, um conjunto de rituais de inversão". Pensado também no seu aspecto "polissêmico, significando coisas diferentes para diferentes pessoas". (SOUZA, 2002, p.v1)

Segundo Pêcheux (1999, p. 49) o acontecimento histórico é "um elemento histórico descontínuo e exterior". Assim sendo e em consonância com o que Souza menciona sobre o burlesco, a agremiação, em seu desfile de 2018, escolheu traçar o prefeito como um rei que não será compreendido pelos seus súditos (eleitores) e será protestado, injuriado e "espancado" em rede nacional, com palavras de ordem no sambaenredo, que aparecerão em nossas análises, em momento oportuno, neste artigo.

Classificamos como acontecimento discursivo, a criação discursiva em si do que produzirá efeitos e sentidos durante sua exibição na avenida, ou seja, é a materialidade do discurso carnavalizado nas alegorias, fantasias e no samba-enredo, esse quando já eleito do processo de eliminatórias, passa a se tornar reprodutor de sentidos. Esse 
acontecimento discursivo surge porque alguém o cria. $\mathrm{O}$ acontecimento discursivo pressupõe, assim,

a relação entre dizeres que, ao se cruzarem, tendem a promover rupturas, ainda que um novo dizer, por princípio, seja formulado a partir das possibilidades que esse dizer encerra. [...] busca-se compreender os acontecimentos discursivos que possibilitam o surgimento de novos espaços de significação para o sujeito. (DELA-SILVA, 2008)

Pêcheux afirma que um acontecimento "é um ponto de encontro entre uma atualidade e uma memória” (PÊCHEUX, 1997, p. 17), ou seja, a história carnavalizada é constituída por uma correlação entre o fato histórico em si e o meio como ele foi concebido e reproduzido no desfile, e de como ele é atualizado e mantido na memória coletiva.

Nessa senda, a Estação Primeira de Mangueira, ao lançar o enredo: "com dinheiro ou sem dinheiro, eu brinco" significa discursivamente com o efeito de acontecimento, na medida que carnavaliza o que já é carnavalizado historicamente - os antigos desfiles, com baixos investimentos e com muita participação popular antes da era do sambódromo - e está contido na memória. Esse acontecimento discursivo é gerado por um conflito da atualidade com a memória "outros antigos carnavais" que não produz repetição, mas sim uma re-significação. Pêcheux mensura que

a memória tende a absorver o acontecimento, como uma série matemática prolonga-se conjeturando o termo seguinte em vista do começo da série, mas o acontecimento discursivo, provocando interrupção, pode desmanchar essa "regularização" e produzir retrospectivamente uma outra série sob a primeira, desmascarar o aparecimento de uma nova série que não estava constituída enquanto tal e que é assim o produto do acontecimento; o acontecimento, no caso, desloca e desregula os implícitos associados ao sistema de regularização anterior. (Pêcheux, 1999, p. 53)

Esse local, rememorado, é o enunciado escolhido pela agremiação para uma resignificação da festa, tomada pelos efeitos da dromologia ${ }^{2}$ e principalmente para emplacar uma crítica aos cortes do financiamento público da prefeitura da cidade do Rio de Janeiro, elementos que serão amplamente explanados a partir da próxima etapa, que relata as condições de produção da Mangueira 2018 e a formação discursiva: "com dinheiro ou sem dinheiro, eu brinco".

\section{CONDIÇÕES DE PRODUÇÃO DA MANGUEIRA 2018: "COM DINHEIRO OU SEM DINHEIRO, EU BRINCO”}

\footnotetext{
2 Dromologia é uma ciência estudada por Virilio (1977) que analisa os efeitos da velocidade processual na sociedade, sobretudo no meio cultural e social, produzidos pela inserção das novas tecnologias na arquitetura, no audiovisual e nos transportes.
} 
Orlandi (2006, p. 17) menciona que "as condições de produção incluem pois os sujeitos e a situação. A situação, por sua vez, pode ser pensada em seu sentido estrito e em sentido lato". Essa condição que é indissociável, estabelece dois momentos:

Em sentido estrito ela compreende as circunstâncias da enunciação, o aqui e o agora do dizer, o contexto imediato. No sentido lato, a situação compreende o contexto sócio-histórico, ideológico, mais amplo. Se separamos contextos imediato e contexto em sentido amplo é para fins de explicação, na prática não podemos dissociar um do outro, ou seja, em toda situação de linguagem esses contextos funcionam conjuntamente.

Reconhecemos que as condições de produção não se inclinam em divisões, mas indo de encontro com os estudos orlandianos, faremos a divisão para que as posições sujeito estejam mais nítidas em nossas discussões.

Assim sendo, ao pensarmos em contexto imediato, as condições de produção da Mangueira em 2018 operam no eixo discursivo: "brincaremos o carnaval de toda maneira", "sem investimentos financeiros públicos, há festa, sim" e "queremos resgatar os antigos carnavais". Ao estabelecermos o sentido mais amplo, as condições de produção: "com dinheiro ou sem dinheiro, eu brinco", detectamos um posicionamento que se projeta em ideologia entre sagrado x profano, a religiosidade x ato de "vadiar" $\mathrm{e}$ ordenamento público x liberdade do povo em festejar e sambar.

O samba sempre foi um ritmo popular muito perseguido. Batista (2017, p. 78) relata que "o samba 'pelo telefone' é considerado o primeiro samba gravado, oficialmente. Sua letra possui inúmeras interpretações e versões, a mais considerada é de que fazia alusão às batidas policiais". Carvalho $(2008$, p. 45) aponta que "a polícia quase sempre fazia batida na casa da Tia Ciata, com o objetivo de prender os 'desocupados' que participavam do candomblé e do samba de terreiro". É nesse sentido que a agremiação Mangueira opera, em posição sujeito de "perseguição", em ato efetivado por agentes do poder público, historicamente.

A maneira que um discurso ocorre são suas condições de produção. Dessa forma, o meio em que ele é produzido possibilita a sua circulação significadora de uma conjuntura dada e estabelecida pelo sujeito. Relata-nos Pêcheux que

um discurso é sempre pronunciado a partir de condições de produção dadas: por exemplo, o deputado pertence a um partido político que participa do governo ou a um partido da oposição; é portavoz de tal ou tal grupo que representa tal ou tal interesse, ou então está 'isolado', etc. Ele está, pois, bem ou mal, situado no interior da relação de forças existentes entre os elementos antagonistas de um campo político dado. O que diz, o que anuncia, promete ou denuncia, não tem o mesmo estatuto conforme o lugar que ele ocupa; a mesma declaração pode ser uma arma temível ou uma comédia ridícula segundo a posição do orador e do que ele representa, em relação ao que diz. Um discurso pode ser um ato político direto ou um gesto vazio, para 'dar o troco', o que é uma outra forma de ação política. (PÊCHEUX, 1997, p. 77) 
Dessa forma, as condições de produção do discurso se posicionam no imaginário do sujeito, em dada posição que ela esteja alocado, diante do cenário de sua formação discursiva, em contraposição ao lugar do outro.

Retomando as condições de produção da FD "com dinheiro ou sem dinheiro, eu brinco", a Escola de Samba Mangueira se inscreveu na posição sujeito de protesto contra o prefeito Marcelo Crivella, baseado em um processo de sucessão de eventos, que passamos a elencar, através de figuras de notícias.

Se Carnaval é um espaço de inversões sociais e de "uma época de desordem institucionalizada, um conjunto de rituais de inversão" (BURKE, 1989), é natural que o oficial ceda espaço às máscaras, fantasias, personagens e sonhos, comandados pelo o Rei Momo. Não é o que tem ocorrido na gestão do atual prefeito do Rio de Janeiro, conforme apresenta a manchete do portal Estadão.

Figura 1. Prefeito não aparece para entrega da chave.

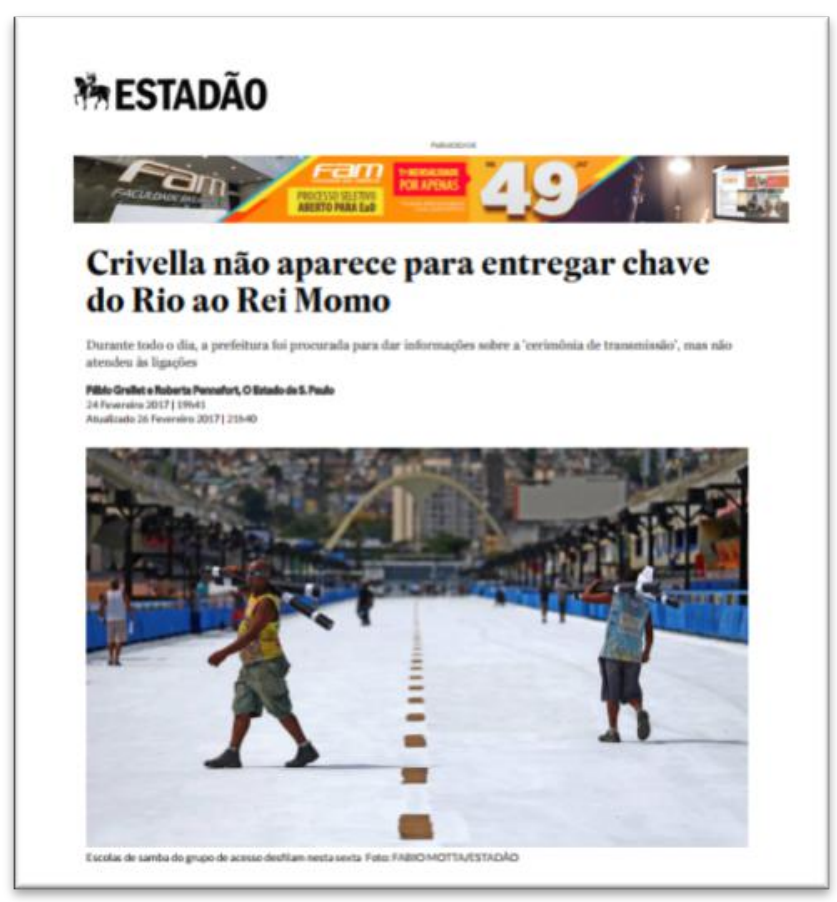

Fonte: http://brasil.estadao.com.br/noticias/rio-de-janeiro,crivella-nao-aparece-para-entregar-chave-do-rioao-rei-momo,70001679111.

Essa ausência de Crivella, significou. Orlandi (2007, p. 29) trabalha a dimensão do silêncio, mensurando que "o homem está 'condenado' a significar. Com ou sem palavras, diante do mundo, há uma injunção à 'interpretação': tudo tem de fazer sentido (qualquer que ele seja)". Esse silenciamento do prefeito às práticas culturais da cidade mais carnavalesca do mundo o inscreveu de imediato na extremidade da ideologia religiosa que o constitui. Isso ocorre, pois, o silêncio

é assim a "respiração" da significação; um lugar de recuo necessário para que se possa significar, para que o sentido faça sentido. Reduto do possível, do múltiplo, o silêncio abre espaço para o que não é "um", para o que permite o movimento do sujeito. (ORLANDI, 2007, p. 13) 
Seguido desse apagamento no período momesco, a prefeitura da cidade do Rio de Janeiro, no dia 12 de junho de 2017, anunciou uma diminuição de metade dos recursos financeiros dos cofres públicos na edição do carnaval de 2018, alegando que utilizará esse montante para pagamentos de creches conveniadas com o município, como verificamos na imagem a seguir.

Figura 2. Prefeito cortará verba destinada ao Carnaval.

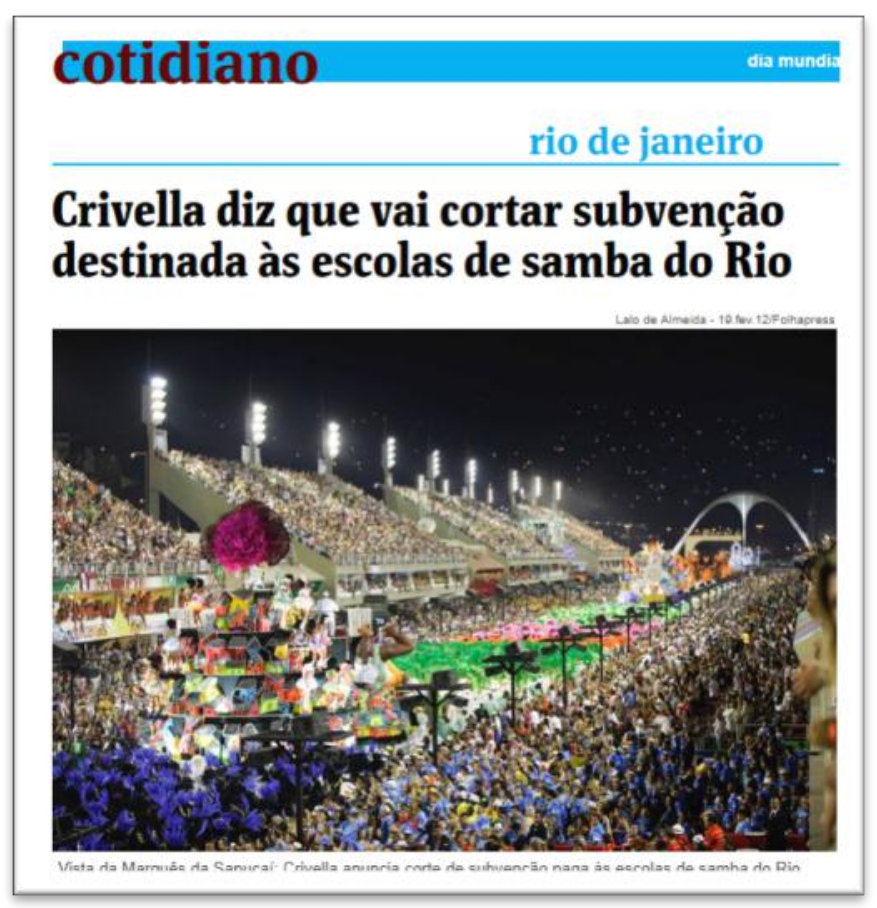

Fonte: http://www1.folha.uol.com.br/cotidiano/2017/06/1892994-crivella-diz-que-vai-cortar-subvencaodestinada-as-escolas-de-samba-do-rio.shtml.

O fato é que a prefeitura arcará com um montante de 13 milhões de reais em 2018, longe dos 26 milhões de reais aplicados na edição de 2017. Crivella, ao reduzir o aporte financeiro aos desfiles, inscreve-se na posição sujeito de autoridade, delegada de poderes e instrumentalizada por atos legislativos oficiais na FD "publica-se, registra-se e cumprase". Dessa forma,

o sujeito da análise de discurso não é o sujeito empírico, mas a posição sujeito projetada no discurso. Isto significa dizer que há em toda língua mecanismos de projeção que nos permitem passar da situação sujeito para a posição sujeito no discurso. Portanto não é o sujeito físico, empírico que funciona no discurso, mas a posição sujeito discursiva. (ORLANDI, 2006, p. 17)

Depreendemos que nessa constante as posições estão claras, "o enunciador e o destinatário, enquanto sujeitos, são pontos da relação de interlocução, indicando diferentes posições sujeito" (ORLANDI, 2006, p. 18). Nesta ocasião, classificamos a Escola de Samba na posição sujeito de prejudicada com a diminuição de recurso, que, pressupõe que foi afetada pela ideologia religiosa do prefeito, se inscrevendo na 
historicidade de abalos e perseguições contra o samba e o Carnaval. Já o mandatário da cidade, se inscreve na posição de gerenciador de recursos, prezando pelo "bom" gasto com saúde e educação, sacrificando, dessa forma, outros setores "menos importantes" da pasta de gestão pública. Isso é o que Orlandi trata como formações imaginárias

que presidem todo discurso: a imagem que o sujeito faz dele mesmo, a imagem que ele traz de seu interlocutor, a imagem que ele faz do objeto do discurso. Assim como também se tem a imagem que o interlocutor tem de si mesmo, de quem lhe fala, e do objeto de discurso. (ORLANDI, 2006, p. 18)

A imagem a seguir, contribuirá para a compreensão das condições de produção da FD "com dinheiro ou sem dinheiro, eu brinco", essa de direcionamento lato, que compreende o contexto sócio-histórico, ideológico, mais amplo: a religiosidade de Marcelo Crivella:

Figura 3. Igreja Universal leva mais de 100 mil pessoas ao sambódromo.

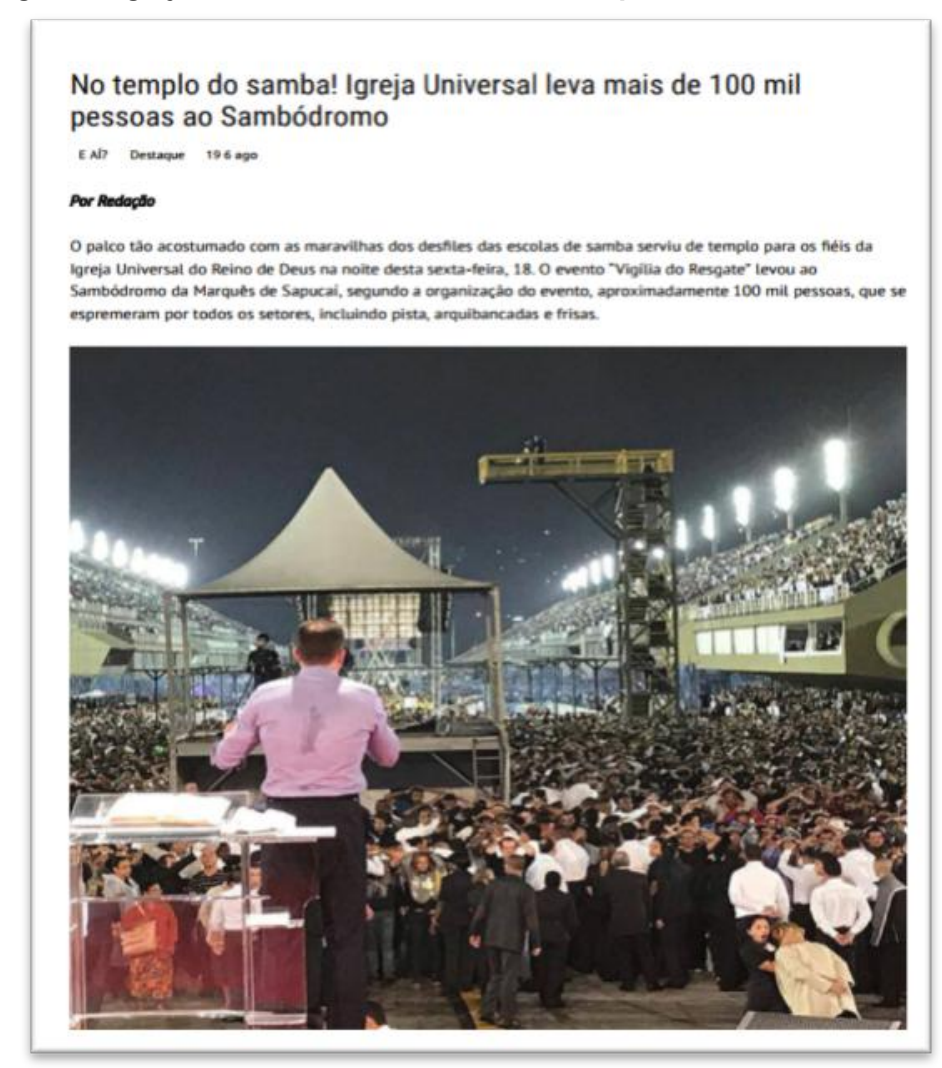

Fonte: https://sambarazzo.com.br/site/e-ai-noticias/no-templo-do-samba-igreja-universal-leva-mais-de-100mil-pessoas-ao-sambodromo.

O prefeito da cidade do Rio de Janeiro, é sobrinho do Bispo Edir Macedo (fundador da igreja universal). Ao alocar mais de cem mil fieis em um espaço claramente do Carnaval, podemos observar uma relação que Orlandi (2006) configura como relações de força. 
Segundo as relações de força, o lugar social do qual falamos marca o discurso com a força da locução que este lugar representa. Assim, importa se falamos do lugar de presidente, ou de professor, ou de pai, ou de filho etc. Cada um desses lugares tem sua força na relação de interlocução e isto se representa nas posições sujeito. Por isso essas posições não são neuras e se carregam do poder que as constitui em suas relações de força. (ORLANDI, 2006, p. 18)

Ocupando o lugar - físico - de samba e Carnaval com um grande evento religioso, o bispo parece querer mostrar que pode ocupar o lugar - social - da festa da carne com o povo sagrado da igreja universal. Essa ação causa o efeito de poder e mostra força político-religiosa do prefeito em territórios do samba.

Com o episódio do corte já consolidado, as agremiações cariocas preparam manifestações, encontros e debates, apostando na concessão de ataques-protestos ao prefeito, a maior ação, foi da agremiação que estamos analisando.

Figura 4. Mangueira anuncia enredo-resposto a Crivella.

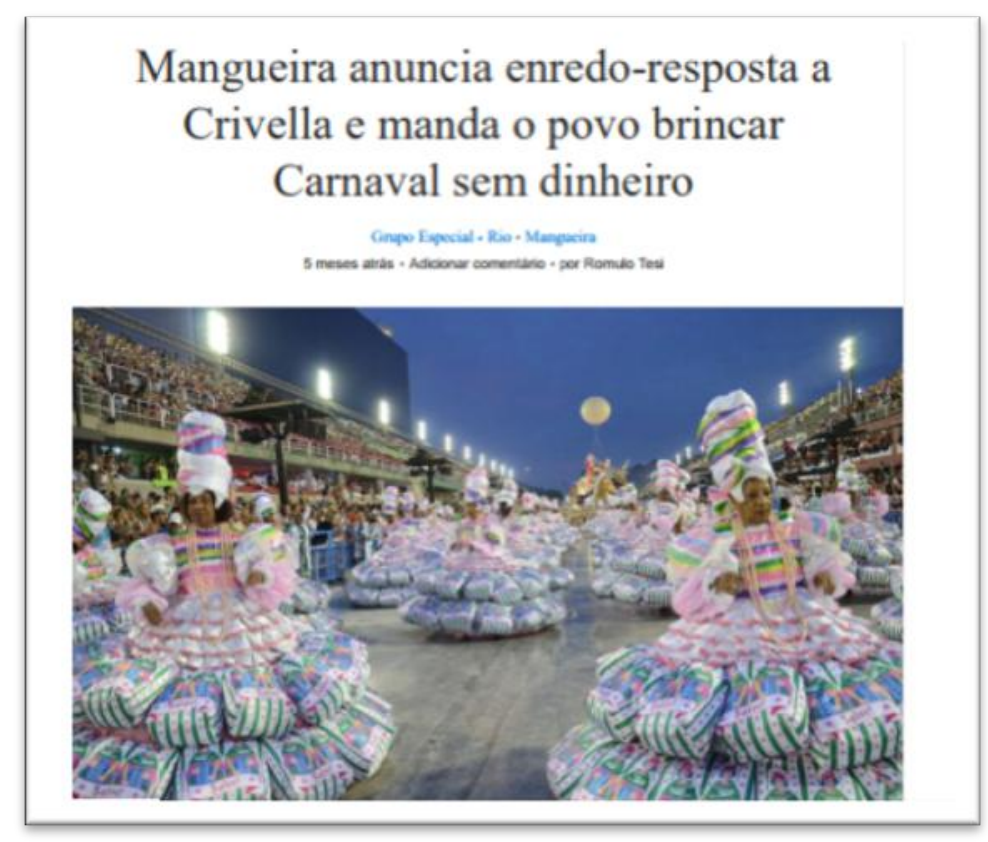

Fonte: http://setor1.band.uol.com.br/mangueira-anuncia-enredo-resposta-crivella-e-manda-o-povobrincar-carnaval-sem-dinheirol.

Antes de entrarmos nas análises e arquiteturas do samba-enredo e fantasias do enredo da Mangueira, precisamos retomar um conceito elaborado por Pêcheux, para melhor compreender a formação discursiva.

Chamamos então de formação discursiva aquilo que, numa formação ideológica dada, isto é, a partir de uma posição dada numa conjuntura dada, determina o que pode e deve ser dito. Portanto, as palavras, proposições, expressões recebem seu sentido da formação discursiva na qual são produzidas. Segundo M. Pêcheux (ibidem) então os indivíduos são interpelados em sujeitos-falantes (em sujeitos de seu discurso) pelas 
formações discursivas que representam na linguagem as formações ideológicas que lhes são correspondentes. É assim que não podemos pensar o sentido e o sujeito sem pensar a ideologia. Do mesmo modo não podemos pensar a ideologia, em termos discursivos, sem pensar a linguagem

Com dinheiro ou sem dinheiro, a escola brinca! FD dada a partir de elementos ideológicos, com posições sujeitos bem definidas e que recebem sentidos na linguagem, aqui de materialidade verbal, através do samba-enredo, e não-verbal, pelo o que é representado nas fantasias, que passaremos a tratar, a partir desse instante.

\section{SENTIDOS E ARQUITETURAS: POLÍTICO E BURLESCO NO SAMBA-ENREDO E EM FANTASIAS NO DESFILE DE 2018}

O samba-enredo é uma poesia escrita, que ganha formas melódicas e desenhos musicais, passando a se tornar o hino da Escola de Samba, ou seja, o samba-enredo a ser cantado por toda a comunidade que ecoará por toda a avenida através de um discurso narrativo, onde e quando vários segmentos artísticos se reúnem para dar voz a um discurso. É uma força enunciativa através de uma estrutura de narração sedimentada que alcançou suas especificidades ao conseguir ser forma única de narrativa: um samba cantado ao longo de todo o desfile repetidamente, para embalar a procissão visual com movimentos que vão numa sequência de alas e carros. Moreira toma o samba-enredo como

um tipo de texto complexo, pois é composto de muitos meios diferentes que, simultaneamente, constroem o seu discurso. Pode-se, assim, chamar a canção de texto sincrético, por ser composta por muitos elementos linguísticos e musicais: melodia, ritmo, harmonia, arranjo ou orquestração, a voz do(s) cantor(es) que a interpreta(m), a letra, a rima e a sonoridade das palavras. (MOREIRA, 2012, p. 3)

$\mathrm{Na}$ contemporaneidade do Carnaval, um samba-enredo antes de ir para avenida precisa se tornar oficial, para isso, (ele) precisa passar por um processo seletivo denominado "Eliminatórias de Samba-enredo", em que cada comunidade abre uma espécie de "edital", com regras específicas para que compositores poetas possam se adequar as exigências das agremiações e dos carnavalescos. As eliminatórias - que trabalhamos aqui na noção de acontecimento político - ocorrem de dois até três meses nas quadras das escolas de samba que entregam premiações em dinheiro para os vencedores. Há um elemento no processo de criação do samba-enredo que não pode deixar de figurar nas suas letras que é o pertencimento à comunidade. Os versos precisam ressoar na voz do componente das escolas de samba o êxtase territorial de ser "da Portela", "da Viradouro", "do Império Serrano", "a minha Mangueira", "ao meu Salgueiro" etc. Esses elementos são sentimentos de identidade e de pertencimento.

O samba-enredo eleito da Estação Primeira de Mangueira para o desfile de 2018, tem um andamento musical que relembra o ritmo das antigas marchinhas de bailes de carnaval, utilizando a prática de repetição, principalmente nos trechos: 
a) "Outrora marginalizado, já usei cetim barato pra desfilar na mangueira". \{duas vezes\}

b) "Se faltar fantasia, alegria há de sobrar, bate na lata pro povo sambar". \{duas vezes\}

c) "Eu sou mangueira, meu senhor, não me leve a mal, pecado é não brincar o carnaval". \{duas vezes\}

Esse jogo da Mangueira que se volta às marchinhas, se remete a memória por um meio metafórico. Por efeito metafórico, Pêcheux (1969) define o efeito semântico que se produz numa substituição contextual. Souza (2002, p. 3) conclui que isto ocorre, "por um deslizamento de sentido numa distância entre $\mathrm{x}$ e $\mathrm{y}$, sendo esta constitutiva tanto do sentido produzido por x como por y" e que "é nesse jogo de deslizamentos que se instituem os movimentos de interpretação (mais ou menos parafrásicos, ou polissêmicos), dando lugar à produção do sentido." (SOUZA, 2002, p. 3). Assim, para a análise de discurso

a metáfora não se coloca nem como comparação, nem como desvio, mas como transferência. Uma transferência que se dá num processo contínuo de deslizamentos, através dos quais é possível se chegar tanto ao lugar da interpretação, quanto ao lugar da historicidade. Por esse caminho é que também se chega à afirmativa de que não há sentido sem metáfora, e de que as palavras não significam por si só. (SOUZA, 2002, p. 3)

Retomam a esse deslizamento, os trechos do samba: "pergunte aos seus ancestrais dos antigos carnavais, nossa raça costumeira", "pra ser feliz de novo, vem como pode no meio da multidão", e "vem vadiar por opção, derrubar esse portão, resgatar nosso respeito". Nessa direção, a agremiação significa, emitindo sentidos nas palavras de que é possível voltar ao passado, aos antigos carnavais livres da competição, aos tempos dos salões e da praça onze. Isso é apurado porque

o sentido se delineia sempre na relação que uma palavra, uma expressão, etc têm na relação com outra palavra, outra expressão, etc. Daí afirmar que "as palavras falam com outras palavras" (Orlandi, 1999a) e se ter com a constatação de que todo discurso vai estar configurado em relação a uma gama de dizeres que ocupam a memória. (SOUZA, 2002, p. 4)

Para a AD a memória discursiva - a memória social - é pensada como um espaço móvel de divisões, de disjunção, de deslocamentos e de retomadas, de conflitos de regularização. (SOUZA, 2002, p. 4) É espaço de desdobramentos, réplicas, polêmicas e contra-discursos. (PÊCHEUX, 1999). É, ainda, pensada na relação com o interdiscurso, definido como a possibilidade mesma de dizer: conjunto do dizível que torna possível o dizer e que reside no fato de que algo fala antes, em outro lugar (ORLANDI, 1999a), enquanto a memória, em termos discursivos, recobre as redes de filiação nas quais o sujeito se inscreve ao produzir o sentido.

Quando a Escola de Samba conclama à memória dos antigos Carnavais ela se inscreve na ideologia de crítica aos gastos demandados pelo espetáculo da dromologia os desfiles contemporâneos que necessitam de altos investimentos - isso aparece nos seguintes trechos. 
a) "Outrora marginalizado, já usei cetim barato, pra desfilar na mangueira"

b) "A minha escola de vida é um botequim, com garfo e faca eu faço meu tamborim"

c) "Firmo na palma da mão, cantando laiálaiá, sou mestre-sala na arte de improvisar"

d) "Não...não liga não, que a minha festa é sem pudor e sem pena"

e) "Volta a emoção, pouco me importa o brilho e renda"

f) "O morro desnudo e sem vaidade, sambando na cara da sociedade"

g) "Se faltar fantasia, alegria há de sobrar, bate na lata pro povo sambar"

No que se refere ao trecho a) "Outrora marginalizado, já usei cetim barato, pra desfilar na mangueira" há uma demonstração de que quando os desfiles eram destinados a "baderneiros" e "gente do morro", as fantasias não careciam de altos investimentos. Em b) "A minha escola de vida é um botequim, com garfo e faca eu faço meu tamborim" aparece um mesmo sentido, em que os batuques não necessitavam de instrumentos musicais. No trecho c) "Firmo na palma da mão, cantando laiálaiá, sou mestre-sala na arte de improvisar" evidencia-se um sentido exacerbado de crítica às alas coreografas com passos duramente marcados da atualidade. Em d) "Não...não liga não, que a minha festa é sem pudor e sem pena" há uma metáfora para mensurar que nos antigos carnavais, as fantasias não precisavam de penas - que geralmente são extraídos de animais - esse sentido de simplicidade das fantasias, também aparecem em e) "Volta a emoção, pouco me importa o brilho e renda", f) "O morro desnudo e sem vaidade, sambando na cara da sociedade" rememorando que muitas passistas desfilavam nuas e g) "Se faltar fantasia, alegria há de sobrar, bate na lata pro povo sambar" emitindo efeito de que sem luxo o povo só precisa sambar e que isso ocorre até se os desfiles não mais existirem nesse formato, ou seja, que de uma forma ou de outra, o povo jamais deixará de brincar.

Ao passo que a Escola Mangueira retoma os antigos carnavais, ela promove um enfrentamento ao prefeito Marcelo Crivella, seja através das suas fantasias ou com palavras de ordem em trechos do samba. Ao criticar o modelo atual de carnaval, a agremiação também quer demonstrar que consegue fazer uma grande festa "sem pudor e sem pena", a exemplo da fantasia que destacamos a seguir.

Figura 5. Um rei que veste pano de prato e trouxinhas na cabeça. 


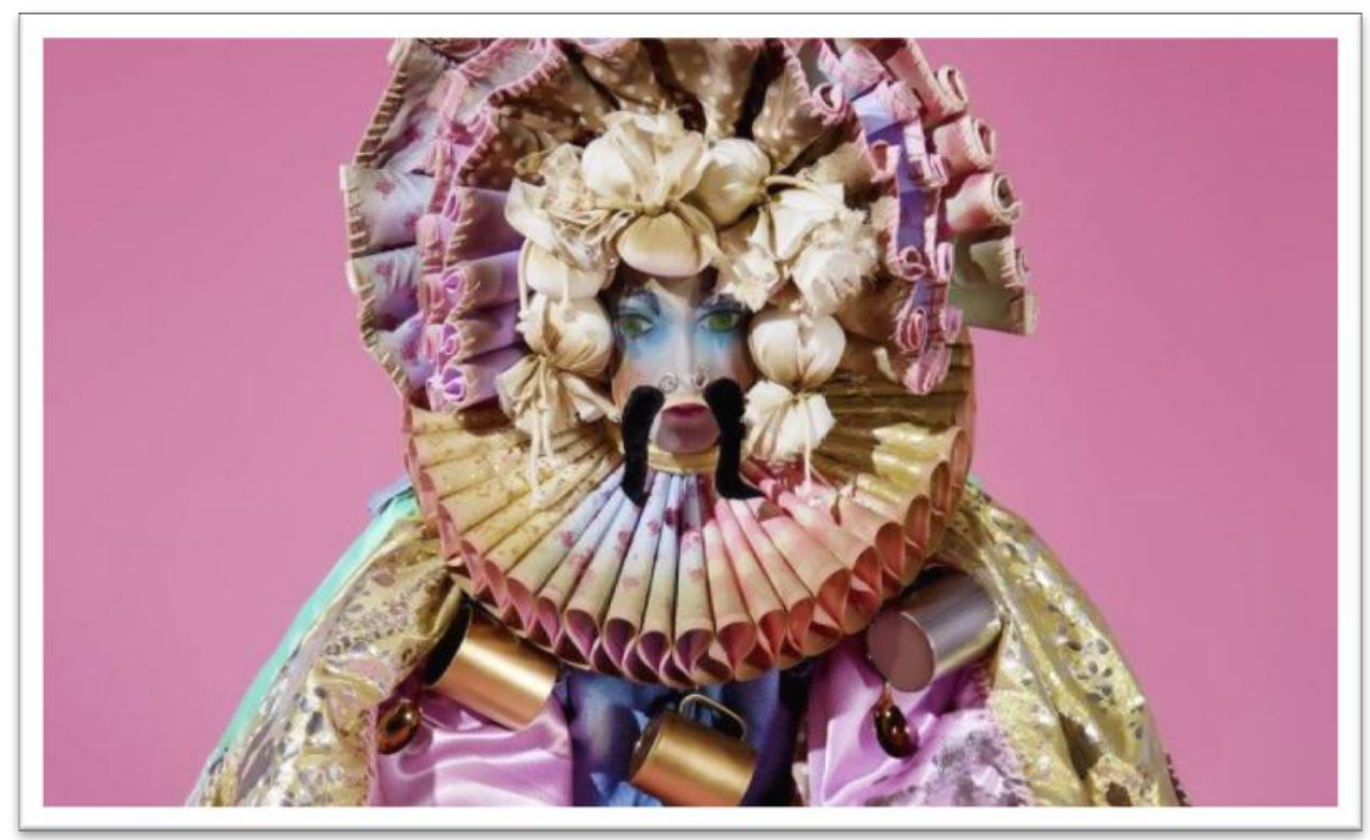

Disponível: Estação Primeira de Mangueira.

Ao pensarmos em análises do não-verbal, devemos apresentar os conceitos pioneiros de Souza (2001). Esses estudos são fundamentais para a compreensão de que as discussões do processo de significação da imagem estão, em geral, restritas a duas vertentes principais.

Ou se toma a imagem da mesma forma como se toma o signo linguístico, discutindo-lhes as questão relativas à arbitrariedade, à imitação, à referenciabilidade, ou se toma a imagem nos traços específicos que a caracterizam, tais como extensão e distância, profundidade, verticalidade, estabilidade, ilimitabilidade, cor, sombra, textura, etc, buscando-se a definição de que modo se dá a apreensão (ou leitura?) da imagem naquilo que lhe seria específico. (SOUZA, 2001)

Nessa direção, optamos pela análise da imagem sob a égide dos traços específicos, buscando para isso, a leitura do gesto de interpretação, pensando o referente como um "objeto imaginário a saber, o ponto de visto do sujeito e não da realidade física", (PÊCHEUX, 1990), "sendo, pois, instituída pelas formações imaginárias e pelos deslizamentos de sentido operados com os gestos de interpretação" (SOUZA, 2001). Nessa senda, Souza aponta que "os referentes não são invariantes primeiros, mas pontos de estabilização de processos discursivos, o que nos faz apontar que a realização de analogia, ou de semelhança pode se dar diferente para cada sujeito" (SOUZA, 2001).

Nesse referente da imagem 4, os panos de prato, as trouxinhas de pano, os laços dobrados e enfileirados, as colheres e as canecas com tecidos que recobrem em formato de capa a roupa do rei, operam no discurso da agremiação emitindo efeito de que com criatividade, o Carnaval não pode perder a majestade no reino da cidade do Rio de Janeiro. O rei não está nu, mas veste roupas simples para brincar e se fazer presente no cortejo dos nobres do Carnaval: o povo. 
$\mathrm{Na}$ fantasia que passamos a analisar a partir desse instante, é possível considerar a figura do mestre-sala sem a sua porta-bandeira, ato impensável nos desfiles da atualidade, uma vez que a PB exerce sua função de bailado com leveza e gingado. Esse apagamento opera com um silenciamento. Vejamos.

Figura 6. Um mestre-sala com colcha de retalhos e sem porta-bandeira.

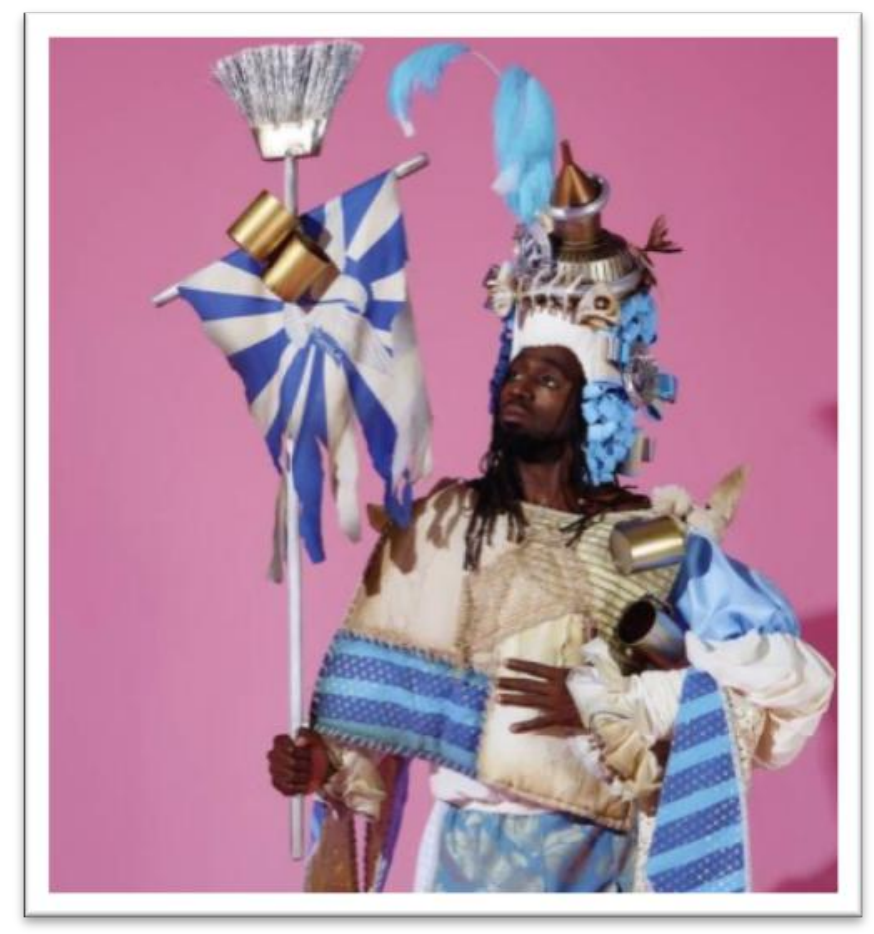

Disponível: Estação Primeira de Mangueira.

Esse silenciamento é dizível quando detectamos a bandeira nas mãos do mestresala, com um cabo de vassoura pintado de metal e latas penduradas. Essa prática ocorre para apagar a porta-bandeira, cuja fantasia custa em torno de trezentos à quinhentos mil reais. Nos estudos sobre o silêncio, Orlandi

observa que os mecanismos de análise que apreendem o verbal através do não-verbal revelam um efeito ideológico de apagamento que se produz entre os diferentes sistemas significantes, dando sustentação, dente outros, ao "mito" de que a língua só pode ser entendida como transmissão de informação, ou como sistema para comunicar. O que leva, por um lado, a estabelecer uma relação biunívoca entre um objeto determinado (verbal ou não-verbal) e o seu sentido e, por outro, a trabalhar não com a materialidade significativa de cada linguagem em si mesma mas sim com a tradução do não-verbal em verbal, mascarando as diferenças, a especificidade de cada uma das formas da linguagem. Os estudos sobre as formas do silêncio vêm a um só tempo contribuir tanto à compreensão da materialidade do não-verbal, quanto à ampliação do objeto da análise do discurso, ao apontar caminhos para se descrever e entender o não-verbal. (SOUZA, 2001, p. 72) 
O mestre-sala da bandeira velha e rasgada, ornamentado com uma colcha de retalhos, cujo chapéu é uma forma de bolo, um funil e a carcaça de um peixe, apresenta o sentido de que nem com toda criatividade e o baixo-custo apresenta "uma beleza", em um dos quesitos mais importantes para julgamento. Sem a porta-bandeira, o mestre-sala significou sem representatividade.

Passamos a abordar os efeitos da ideologia religiosa e da relação "burlesco x político" no discurso da agremiação.

Orlandi (2006, p. 22) retrata que "a ideologia interpela o indivíduo em sujeito e este submete-se à língua significando e significando-se pelo simbólico na história". Na letra do samba-enredo o enfrentamento à religiosidade do prefeito, registra-se no refrão principal, que se repete: "Eu sou Mangueira, meu senhor, não me leve a mal, pecado é não brincar o carnaval". Dessa maneira, a posição sujeito Escola de Samba, se assujeita à posição sujeito "meu senhor", mensurando-o como ser superior, significando ao "senhor" Crivella ou ao "senhor Jesus". Quanto ao assujeitamento, afirma-se que

quando se afirma que o sujeito é assujeitado, não se está dizendo totalmente, parcialmente, muito ou pouco, ou mais ou menos. O assujeitamento não é quantificável. Ele diz respeito à natureza da subjetividade, à qualificação do sujeito pela sua relação constitutiva com o simbólico pela ideologia. (ORLANDI, 2006, p. 22)

Souza (2001, p. 73) mensura que "a imagem em sua especifidade se constitui em texto, em discurso" e ao "se interpretar a imagem pelo olhar - e não através da palavra apreende-se a sua matéria significante em diferentes contextos". Para a pesquisadora "o resultado dessa interpretação é a produção de outras imagens, produzidas pelo espectador a partir do caráter de incompletude inerente, eu diria, à linguagem verbal e não-verbal. $\mathrm{O}$ caráter de incompletude da imagem aponta, dentre outras coisas, a sua recursividade. Quando se recorta pelo olhar de um dos elementos constitutivos de uma imagem produzse outra imagem, outro texto, sucessivamente e de forma plenamente infinita".

Nesse contexto, ao olharmos para a próxima fantasia que trouxemos para as nossas discussões, encontramos o que pensamos que do assujeitamento (re)aparece e (re)significa como efeito da produção de uma outra imagem, ou outro texto. Vejamos:

Figura 7. Malandro sambista resignificado. 


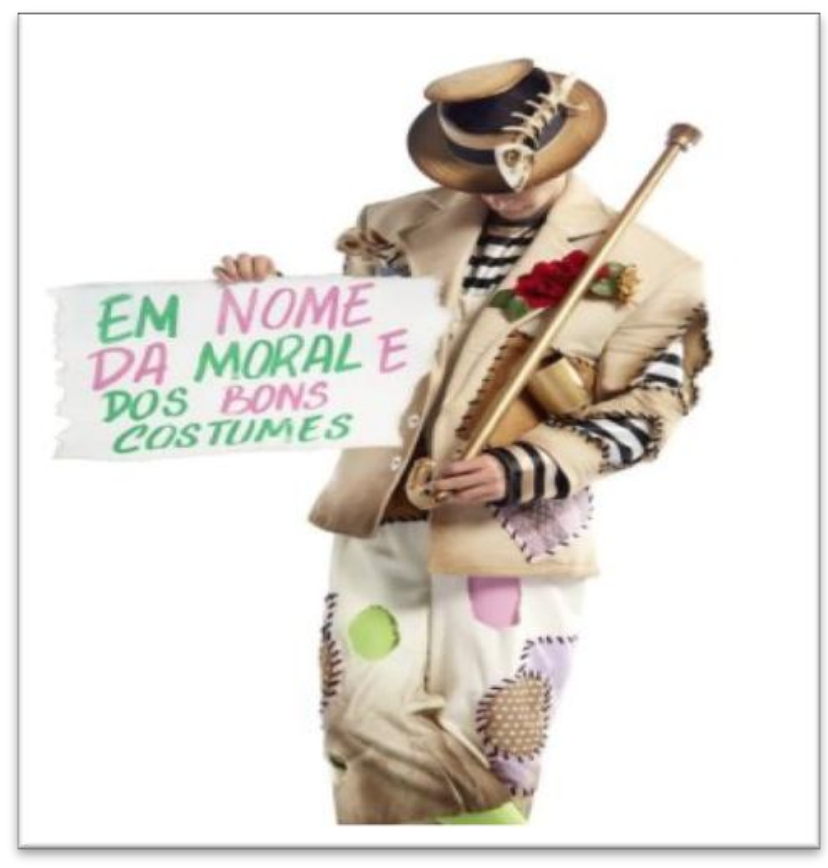

Disponível: Estação Primeira de Mangueira.

A reprodução da fantasia, emite o sentido de que o malandro sambista está preso e sem vida em nome da moral e dos bons costumes -emanados pela ideologia religiosa do prefeito do Rio - em um país em que muitos políticos deveriam estar presos, preso está o sambista por não seguir essa ideologia (do prefeito). Esse sentido significa na figura do malandro carioca, que vem acometido das listras da roupa do malandro, que se ressignifica com o paletó rasgado e a calça com retalhos que dão o tom da economia.

Na relação "burlesco x político, os trechos que operam esse sentido são: "chegou a hora de mudar, erguer a bandeira do samba", "vem a luz à consciência que ilumina a resistência dessa gente bamba", "somos a voz do povo, embarque nesse cordão", "vem pode chegar que a rua é nossa mas é por direito". Esse sentido pode ser pensado como forma burlesca de insurreição, de crítica, de protesto. Este traço característico do carnaval - que joga com o escárnio, com a ironia, dando fim a um "reinado" - se ilustra bem a esse enredo da Mangueira. A Mangueira 2018, clama pelo fim de um reinado puramente ideológico e religioso que está afetando as manifestações culturais populares no âmbito do Rio de Janeiro. Crivella está condenado a significar no implícito da crise financeira por motivos outros. Souza (2001. p. 13) aponta que

o implícito é dado, está -lá . Mas de uma forma outra, travestido, mascarado e, quase sempre, destituído do sentido implícito, pressuposto, quando é re-significado na materialidade do burlesco. Desvelando, ao mesmo tempo, as formas de silenciamento $\mathrm{e}$ apagamento.

Postulado nossos objetivos de discussões, apresentaremos nossas breves considerações sem a pretensão de fechamento conclusivo, mas para abertura de diálogos outros e vindouros.

\section{BREVES CONSIDERAÇÕES}


Ao trabalharmos o entrelaçamento linguístico e artístico, através dos sentidos e arquiteturas que possibilitaram os diálogos sobre a discursividade no enredo da Estação Primeira da Mangueira, fomos constituídos da missão de levantar o político e o burlesco na materialidade de nossas discussões.

Passamos aqui por inúmeros aparatos da AD francesa em Pêcheux, Orlandi e pela arquitetura do não-verbal em Souza.

A temática Carnaval perpassa por nossa linha de investigações aliando outras contribuições, no sentido de propagar sentidos e espaços par diálogos sobre essa importante celebração brasileira.

Aqui chegamos com proposituras prévias de que a autoridade "Marcelo Crivella" é alvo de crítica jamais vista na era dromológica de Carnaval, principalmente por significar logo no início de seu mandato com uma ausência constitutiva na cerimônia da entrega das chaves da cidade - de maneira simbólica - ao rei momo.

A partir desse acontecimento, o destino de Crivella no Carnaval foi fundado. Logo veio a diminuição dos investimentos públicos na edição de 2018 e outros indicadores de que ideologicamente, o prefeito da cidade samba, seria avesso ao Carnaval. Não nos cabe o julgamento, apenas os diálogos à luz da AD.

Ao anunciar seu enredo, a Escola Mangueira, não lançou uma "marca" de enredo, e sim quatro, são as chamadas logos que mostramos a seguir:

Figura 8. Logotipos de enredo da Mangueira.
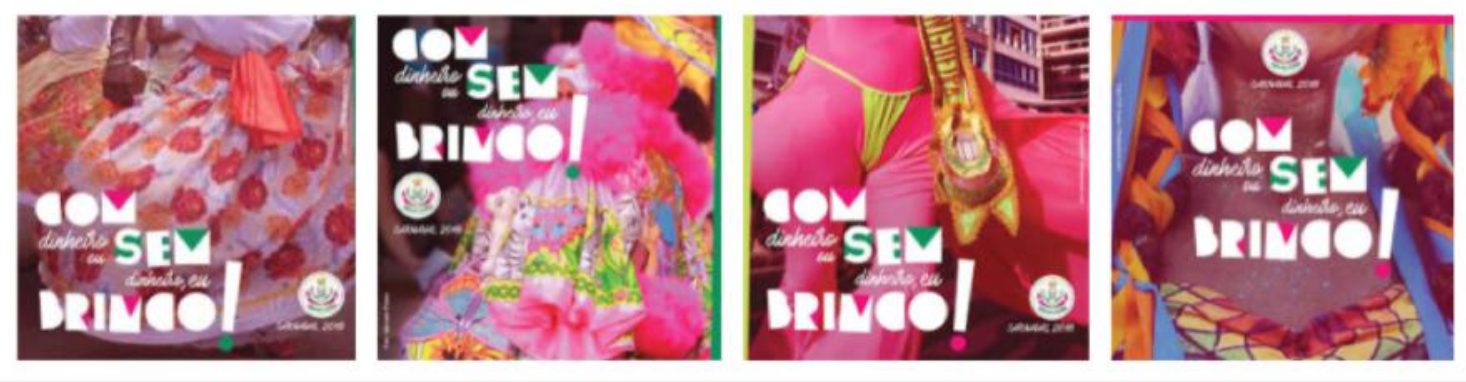

Disponível: Estação Primeira de Mangueira.

Com essa noção de pluralidade, a Escola pede que cada brincante escolha a arte (logo) que quiser para que seja a sua oficial. E esse é a tonalidade que molda a agremiação em 2018, que causa um efeito de que escolha o que você quer ser, brinque da forma que você achar melhor e não deixe de aproveitar o seu carnaval. Brinque! Constituída por essa ideologia "com dinheiro ou sem dinheiro", a Escola pede resistência à sua comunidade: "vem a luz à consciência que ilumina a resistência dessa gente bamba", convida o público para um desfile de cordão - rememorado - "somos a voz do povo, embarque nesse cordão, pra ser feliz de novo" e propõe uma reaproximação do Carnaval com o população 
economicamente de média e baixa renda, visto que os valores dos ingressos são altos: "vem vadiar por opção, derrubar esse portão", o portão aqui, é o do sambódromo.

Finalizamos, mas, querendo estabelecer futuros diálogos e olhares sobre esse desfile. Nesse ciclo atual, encerramos com a certeza de que nos desfiles Carnaval, as Escolas de Samba estão autorizadas a narrar o que quiserem, mas quando narram, se filiam à posições discursivas através de sua materialidade que se alegoriza através de carros, fantasias, adereços e samba-enredo. A AD das nossas investigações respeita o estado catártico e misterioso que o carnaval provoca nas pessoas, mas extrai elementos da memória, do político, do acontecimento, do ideológico, das condições de produção, passando a ser o carnaval dos efeitos, das arquiteturas e dos sentidos.

\section{REFERÊNCIAS}

BATISTA, Tiago José Freitas. Narrativas poético-musicais-amazônidas na dromologia do carnaval carioca e paulistano: indigenismo, folclorismo e africanidades religiosas. Dissertação. Mestrado Acadêmico em Letras, Núcleo de Ciências Humanas, Universidade Federal de Rondônia, 2017.

BURKE, P. A Cultura Popular na Idade Moderna. São Paulo: Cia das Letras, 1989.

CARVALHO, C.M.S. de. Samba de partido-alto e o turismo cultural no Rio de Janeiro: terreiros, pagode e culinária. São Gonçalo: Universidade Paraíso, 2008.

DELA-SILVA, Silmara Cristina. O acontecimento discursivo da televisão no Brasil: a imprensa na constituição da TV como grande mídia. Tese. Doutorado em Linguística. IEL, Unicamp, Campinas, 2008.

LE GOFF, Jacques. História e Memória. 4ª ed. Campinas: Ed. da Unicamp, 1996.

MOREIRA, Renata Lúcia. Quem é esse cara? A ilusão enunciativa na canção "Esse cara sou eu". São Paulo. 2012. Disponível em: http://www.mackenzie.br/fileadmin/Pos_Graduacao/Doutorado/Letras/Cadernos/Volum e_1_2014/Quem_e_esse_cara_A_ilusao_enunciativa.pdf. Acesso em $12 \mathrm{de}$ dez. 2017.

ORLANDI, E.P. As formas do silêncio. Campinas: Ed. da Unicamp, 2007.

Discurso e Textualidade. Campinas: Editora Pontes, 2006.

PÊCHEUX, Michel. Papel da Memória. Em: ACHARD, Pierre et. al. Papel da Memória. Trad. Bras. Campinas: Pontes, 1999.

Análise Automática do Discurso (AAD-69). Em: GADET, F.; HAK, T. (Org.). Por Uma Análise Automática do Discurso: uma introdução à obra de Michel Pêcheux. $3^{\text {a }}$ ed. Campinas: Editora da UNICAMP, 1997.

SOUZA, T.C.C. Carnaval e memória: das imagens e dos discursos. [Anais] Associação Nacional de Pós-Graduação e Pesquisa em Letras e Linguística [Anpoll], 2002. 
Disponível

em:

http://www.leffa.pro.br/tela4/Textos/Textos/Anais/ANPOLL_2002/arquivos/pdf/002 an alise discurso/tania clemente.pdf. Acesso em 14 dez. 2017.

A análise do não verbal e os usos da imagem nos meios de comunicação. Rua, 7, Campinas, LABEURB, UNICAMP, 2001.

Artigo recebido em: dezembro de 2017.

Aprovado e revisado em: abril de 2018.

Publicado em: maio de 2018.

\section{Para citar este texto:}

BATISTA, Tiago José Freitas. O político e o burlesco na Mangueira 2018: arquitetura e sentidos. Entremeios [Revista de Estudos do Discurso, ISSN 2179-3514, on-line, www.entremeios.inf.br], Seção Temática [Discurso, arte e literatura - Parte I], Programa de Pós-Graduação em Ciências da Linguagem (PPGCL), Universidade do Vale do Sapucaí (UNIVÁS), Pouso Alegre (MG), vol. 16, p. 307-326, jan. - jun. 2018.

DOI: http://dx.doi.org/10.20337/ISSN2179-3514revistaENTREMEIOSvol16pagina307a326 